\title{
Testing the Validity and Reliability of Metaseller Tutoring Module for the Purpose of Mathematics Learning Intervention
}

\author{
Mohamad Ariffin Abu Bakar*, Norulhuda Ismail \\ School of Education, Faculty of Social Sciences and Humanities, Universiti Teknologi Malaysia, Malaysia
}

Received October 24, 2019; Revised January 21, 2020; Accepted February 25, 2020

Copyright $\bigcirc 2020$ by authors, all rights reserved. Authors agree that this article remains permanently open access under the terms of the Creative Commons Attribution License 4.0 International License

\begin{abstract}
The level of mastery of mathematics is evidence to evaluate the excellence of the school mathematics curriculum. However, the effectiveness of the delivery of mathematical learning remains an issue when the level of mastery is still low. Therefore, curriculum transformation is required to ensure that mathematical mastery is at a satisfying level. Various suggestions and interventions have been undertaken to enhance the mastery of students' mathematical concepts and achievements, including through the construction of teaching modules. Therefore, the objective of this study is to develop the Meta-Seller Tutoring Module (M-ST) and subsequently determine the validity and reliability of the module. This M-ST module is developed through a design and development research that takes the ADDIE Model as an instructional design guide. This M-ST module incorporates peer tutoring and metacognitive learning strategy models as it is content and module activities to help the improvement in students' mastery of mathematics. A total of 10 experts, a mathematics teacher, and 31 students participated in the study to determine the content validity and reliability of the module. The results of the analysis of the content validity of the module found that it is in an excellent rank with a validity index of 0.86 . While the value of the reliability coefficient is 0.953 which also indicates that this module is at a very high level of trust. Based on the results, it can be concluded that this module is very useful and can be used as an intervention in mathematics learning. Teachers can integrate this module into teaching and learning to produce effective mathematics learning. By using this module, teachers can provide students with learning aids through interactive materials to create active learning.
\end{abstract}

Keywords Validity and Reliability, Instructional Module, Mathematics Learning, Metacognitive Strategy, Intervention

\section{Introduction}

Curriculum transformation within a country is implemented where needed, in line with current developments in the country and global issues. This transformation will ensure that students are provided with sufficient knowledge and competency to address the current industry needs. The learning approach will be updated with practical findings based on the latest trends. Teaching modules are also not exempted where there are various modules produced through research and innovation. Not a few modules have been produced, and models of academic module development have been purposed such as ADDIE Model, Dick \& Carey Model (1990), Sidek's Module Development Model (2005), Marisson Model (2007) and so on (Darussalam \& Hussin, 2018). However, according to Lim (2016) and Go Silk, Go Silk \& Somblingo (2017) there are relatively fewer modules produced in mathematics education especially modules for problemsolving teaching intervention. To ensure that mathematics learning is effective for student mastery, a mathematics learning module should also be developed.

Mathematics is a subject that is still misinterpreted due to the nature of the subject being abstract and quite complex (Hasbullah, 2015; Crish, 2015; Lim, 2016). Mastery of mathematics concepts is still at a low level, and students are still unable to solve non-routine mathematics problems and questions that form the test high-order thinking skills (HOTs) as reported in Go Silk, Go Silk \& Somblingo (2017). This indicates that further studies need to be carried out to see what the real weaknesses are. Further solutions should be provided to ensure that the level of mathematics mastery can be improved. According to Lim (2016) and 
Festus (2017), one of the factors that led to weak mathematics mastery was the learning activity factor. According to Phi (2017), teachers neglect students' metacognitive abilities in learning, whereas it is the metacognitive skills that influence students' actions in managing learning. Therefore, activities that teachers create as a medium of delivering knowledge and mathematical concepts, should be able to motivate, enhance active engagement and most importantly can develop students' metacognitive aspects. So, researchers are developing activities that can train the metacognitive aspects as well as shape a more structured and systematic teaching approach.

\section{Literature Review}

The definition of metacognition as defined by Schraw \& Moshman (1995), Nelson \& Narens (1990), PapaleontiouLouca (2008) as "cognition about cognition" or "thinking about thinking" is about setting goals, ways and thinking that students need to manage during the learning process. It is compatible with mind-on mathematics learning that requires critical and creative thinking skills as well as skills in self-learning (Smith \& Mancy, 2018; Hasbulah, 2015). The learning needs and goals are only understood by the student himself according to the situation and the content of the lesson based on his metacognitive experience (Papaleontiou-Louca, 2008). According to Menz \& Cindy Xin (2016) direct-acting, metacognition enables students to organize their learning, assess their abilities and build confidence. According to Zumbrunn, Tadlock \& Roberts (2011), it is a process of metacognitive regulation in which students manage their thinking activities, determine behaviors and shape emotions so that learning is meaningful to them. This metacognitive regulation factor was recognized by Smith \& Mancy (2018) who was able to increase students' mastery of mathematics concepts. A metacognitive learning strategy can be developed when the method or learning technics promotes the development and application of metacognitive skills (Papaleontiou-Louca, 2008; Menz \& Cindy Xin, 2016). Among the metacognitive learning strategies practiced by teachers are problem-solving approaches, task or project learning, game simulation, case study, innovation, and design as well as other methods that focus on cognitive training and metacognitive skills (Elliot, 1993).

Panaoura, Gagatsis \& Demetriou (2009) discuss that mathematics learning based on metacognitive learning strategies must adhere to several aspects to enhance effectiveness, including:

a. Students need to understand the phenomena in their learning tasks, which can be related to activities, orientation and learning situations

b. Students' activities need to be in line with the discipline and the proper method of implementation c. Systematically performs the work to achieve a solution to the real-life situations revealed in the activity

d. Evaluate activities by examining the results, suitability and potential of mathematics knowledge obtained in real problems

Learning through activities can produce meaningful learning that can impact students' mathematics mastery over traditional learning methods (Festus, 2017; Rillero, 2016; Benders, 2016). Festus (2017) argues that improper teaching methods can lead to declining mathematics, but through active activity can result in meaningful learning. Therefore, to enhance thinking skills and to develop metacognitive skills in mathematical learning, it requires interactive learning activities. This opinion is supported by Celik (2018) who concludes that interactive activities can enhance critical thinking, appreciation, responsibility and group interaction. An example of this interactive activity is peer tutoring. This activity can train collaborative and thinking skills (Arrand, 2014; Pilten, 2016). According to Arrand (2014) and Hott \& Walker (2012), peer tutoring can shape interactions between peers such as mentoring and coaching. Students who serve as tutors will assist their tutees in solving mathematics problems. This will optimize interactions and thus develop metacognitive skills. Selfregulation of metacognitive aspects such as action planning, monitoring and evaluating learning can be practiced during peer tutoring activities where students have the opportunity to compare their understanding through the role they play and interact with peers. This has been proven in a study conducted by Acar \& Ader (2017), Arrand (2017) and Hott $\&$ Walker (2012) report that peer tutoring activities can enhance metacognitive regulation and effectively influence students' thinking skills. In this regard, studies by $\mathrm{Al}$ Kharusi (2016) and Hussein, Anwar \& Majoka (2011) found that during peer tutoring activities, students are more efficient and able to master learning more effectively. The findings obtained by Al Kharusi (2016) show that students are more proficient in the aspects of time management as well as solving mathematics problems accurately. Cera, Mancini \& Antonietti (2013) and Du Toit \& Du Toit (2013) illustrate that when students can manage their learning needs and use their time effectively in completing assignments, they have mastered metacognitive actions. It can be concluded that, through peer tutoring, metacognitive skills and thinking skills can be improved.

\subsection{Meta-Seller Tutoring Module}

For intervention in mathematics learning, this module is designed to provide effective mathematics learning activities. This activity is a peer tutoring model application that will enhance student interaction and collaboration. Besides, students' metacognitive skills will be targeted for improvement during activities to achieve the goal of increasing student mastery of mathematics concepts. 
Beginning with the concept of active learning through Constructivist Theory and Vygotsky's Theory, the researcher designed and developed the module by applying ASK Model of Peer Tutoring purposed by Fitch \& Semb (1993) and through Metacognitive Theory, a metacognitive learning strategy model, Anderson's Model (2002) was applied. The table below shows the development of the module based on components suggested in the ASK Model and Anderson's Model.

Table 1. Model's Components and Development of M-ST's Subactivity

\begin{tabular}{|c|c|c|}
\hline $\begin{array}{c}\text { ASK } \\
\text { Model }\end{array}$ & Anderson's Model & $\begin{array}{l}\text { Subactivity of M- } \\
\text { ST Module }\end{array}$ \\
\hline Attitude & $\begin{array}{c}\text { Preparing and } \\
\text { planning for learning }\end{array}$ & $\begin{array}{l}\text { Subactivity 1: } \\
\text { Seller-customer } \\
\text { selection }\end{array}$ \\
\hline \multirow[t]{2}{*}{ Skills } & $\begin{array}{l}\text { Selecting and using } \\
\text { learning strategies }\end{array}$ & $\begin{array}{c}\text { Subactivity 2: } \\
\text { Marketing } \\
\text { planning }\end{array}$ \\
\hline & $\begin{array}{c}\text { Monitoring strategy } \\
\text { use }\end{array}$ & Subactivity 3: \\
\hline \multirow{2}{*}{ Knowledge } & $\begin{array}{c}\text { Orchestrating various } \\
\text { strategies }\end{array}$ & Promotion time \\
\hline & $\begin{array}{l}\text { Evaluating strategy } \\
\text { use and learning }\end{array}$ & $\begin{array}{c}\text { Subactivity 4: } \\
\text { Bestseller award }\end{array}$ \\
\hline
\end{tabular}

Source: Fitch \& Semb (1993) and Anderson (2002)

Therefore, this module is the independent variable of the study. Evaluation of the module is based on the effectiveness of the students' mastery. Therefore, the dependent variable in this study is the students' mastery. Meanwhile, metacognitive regulation skills act as a moderator variable. According to Darussalam \& Hussin (2018), moderating variables were selected and determined by researchers to change the relationship between independent variables and dependent variables that would be effective in either weakening or strengthening one of them. The design of this study is development research by applying the instructional design model which is the ADDIE Model. Researchers have chosen the ADDIE model because the development of this module is part of the teaching method that develops learning activities in the form of a game. The design and development are based on the steps suggested in the ADDIE model, which are Analysis, Design, Development, Implementation, and Evaluation. The researcher has divided the process of development of this module into three phases, the first phase being the phase of the needs analysis in which a survey is conducted to find out the needs of module development and to formulate the objectives of the module. The second is the design and development phase of the module. In this phase, the contents of the module and module activities are created and developed based on the theory and model selected. The final phase is the implementation and evaluation phase of the module. In this phase, a pilot study and expert evaluation are performed to obtain the validity of the module content and the reliability of the activities in the module.

\section{Methodology}

The study has two kinds of objectives: general and specific objectives. The general and main objective of this study is to develop a Meta-Seller Tutoring module focusing on increasing the metacognitive skills of mathematics students. The specific objectives of this study are to validate the module by mathematics education experts and to perform a reliability check among the students before the real study is conducted. In summary, the study aims to develop a learning intervention by merging of metacognitive strategy and peer tutoring concept to enhance student's mastery in mathematics. The module is named as the Meta-Seller Tutoring (M-ST).

\subsection{Research Instruments and Procedure}

The quantitative approach was implemented as a research method with two questionnaires developed by the researcher used as instruments in this research. Guided by the relevant literature, the researcher synthesized the needs of module development that modifies the implementation of peer tutoring activities by adding subactivity to metacognitive regulation skills. In this study, the questionnaire was administered to determine the validity of the module namely face validity and content validity. The face validity of the module is examined by two experts, a language and a mathematics education expert. Experts have evaluated the draft module as well as the questionnaire to be used. Based on the review, the experts recommend several improvements, including spelling, sentence structure, and main points for each questionnaire to achieve dimension in the study. The next stage is to administer the validity of the module content after the draft module has been modified involving a panel of experts or external critics. The panel of assessors selected in this study comprises ten experts, based on their extensive experience and expertise in mathematics, module development, teaching and learning mathematics. Each expert is firstly contacted for getting the approval. The experts will be given a copy of the module and will take about 2 to 4 weeks to review. Meetings and discussions will be conducted for further detail along with expert evaluation and scoring using relevant questionnaires. Expert's criticism and suggestions for improvement of all sections of this module are rated on a scale, from 1 (strongly disagree) to 10 (strongly agree). To determine the value of content validity, the raw data were computed using the formula as follows: Total Score of Individual Expert's Rating (X) was divided by the Overall Score of Rating (Y). This value will give the module value validity as a percentage $(\%)$ where if the value exceeds $70 \%$, the module has high validity, then the percentage value can change into index form, where 100 percent as 1.00 and 0 percent as 0.00 (Noah \& Ahmad, 2005).

Next, to assess the reliability of the module, the 
researcher used the questionnaire to obtain the consent of the students targeted as users of this module. This is based on the method that Russell (1974), as confirmed and implemented by Jalil \& Mahfar (2016) and Madihie \& Noah (2013), successfully introduced and adapted by Noah \& Ahmad (2005). In this study, the sample should complete the 49 items based on the overall activities and 4 subactivities. This questionnaire was distributed after they had completed the learning of selected topics in mathematics based on the module. Then, the questionnaires were analyzed using Cronbach Alpha to obtain the reliability coefficient of the module. According to Jalil \& Mahfar (2016), the value of reliability is a formative assessment for researchers to index whether they can achieve the objectives and see the suitability of activities against time and target groups as well as a review of the accuracy of the instructions and steps in module activities.

\subsection{Participants}

To determine the content validity of the module, the researcher selected ten experts based on their experience and expertise in mathematics, module development, teaching and learning mathematics. Subsequently, a total of 31 students and one mathematics teacher from a secondary school were selected to take the pilot study using the module. According to Cooper and Schinler (2006) in Darussalam \& Hussin (2018), the sample size between 20 and 100 was sufficient for reliability studies, as the purpose of this study was to look at the usefulness and clarity of the module's objectives. The mathematics teacher will conduct a mathematics learning session by following the original class schedule and current topic using the module. Then, a questionnaire was given to the participants to assess the reliability of the module based on the behavior of performing each module activity

\section{Results and Discussion}

\subsection{Validity of Module}

A total of 10 experts are involved in reviewing and evaluating the content and suitability of the module. The following table shows the findings from the expert ratings.

Table 2 reveals the overall results from the M-ST Module validity test based on each item's statement. The module's validity test results showed that the value of the content validity coefficient was $0.86(85.8 \%)$. The values for each item range from 0.81 to 0.90 . Most experts agreed with the statement that the M-ST Module content can meet the target populations resulting in the highest validity coefficient score of 0.90 . And followed by the content validity coefficient of 0.88 and 0.87 respectively, which refers to the content of the module that can develop the metacognitive regulation of the students and can affect the mastery of the student in mathematics. Whereas the two statements related to the M-ST Module content can be successfully implemented and consistent with the allocated time, the content validity coefficients of 0.83 and 0.81 were acquired accordingly. According to Noah \& Ahmad (2005), the evaluation of good content validity is based on Tuckman and Waheed's (1981) view that $70 \%$ of the level achievement is considered as being a higher level of achievement. It means that if the percentage obtained is above $70 \%$ or vice versa, the module will have reasonable content validity.

Table 2. Analysis of Validity Coefficient for M-ST.

\begin{tabular}{|c|c|c|c|c|}
\hline \multicolumn{2}{|r|}{ Item Statements } & \multirow{2}{*}{$\begin{array}{c}\begin{array}{c}\text { Percentage } \\
(\%)\end{array} \\
90\end{array}$} & \multirow{2}{*}{$\begin{array}{c}\begin{array}{c}\text { Validity } \\
\text { Index }\end{array} \\
0.90\end{array}$} & \multirow{2}{*}{$\begin{array}{c}\text { Expert's } \\
\text { Judgment } \\
\text { Accepted }\end{array}$} \\
\hline 1. & $\begin{array}{l}\text { The contents of } \\
\text { this Meta-Seller } \\
\text { Tutoring Module } \\
\text { fit the target group }\end{array}$ & & & \\
\hline 2. & $\begin{array}{l}\text { Meta-Seller } \\
\text { Tutoring Activity } \\
\text { has the potential to } \\
\text { be fully } \\
\text { implemented }\end{array}$ & 83 & 0.83 & Accepted \\
\hline 3. & $\begin{array}{l}\text { This Meta-Seller } \\
\text { Tutoring activity is } \\
\text { appropriate for the } \\
\text { time allocated }\end{array}$ & 81 & 0.81 & Accepted \\
\hline 4. & $\begin{array}{l}\text { Meta-Seller } \\
\text { Tutoring Activity } \\
\text { has the potential to } \\
\text { enhance students' } \\
\text { metacognitive } \\
\text { regulation }\end{array}$ & 88 & 0.88 & Accepted \\
\hline 5. & $\begin{array}{l}\text { Meta-Seller } \\
\text { Tutoring activities } \\
\text { have the potential } \\
\text { to impact on } \\
\text { student mastery }\end{array}$ & 87 & 0.87 & Accepted \\
\hline & Overall content & 85.8 & 0.86 & Accepted \\
\hline
\end{tabular}

Generally, all ten experts agreed that the contents of the M-ST module are relevant to the purpose of the item statements and appropriate for implementation in mathematics learning. At the same time, the findings of this study showed that the content of the M-ST Module is statistically significant and has good content quality because it met the five content validity criteria demonstrated by Russell (1974) as mentioned in Noah \& Ahmad (2005). Also, the researcher determines the validity of the activities in the module to see in more detail whether the development of module activity meets the objectives and learning dimension, which is whether the activity can affect each students' metacognitive regulation skills aspect. The evaluation is also to look at the strength of each activity in content. 
Table 3. Content Validity Percentages for the Activities of Module.

\begin{tabular}{cccc}
\hline Activities & $\begin{array}{c}\text { Percentage } \\
(\%)\end{array}$ & $\begin{array}{c}\text { Validity } \\
\text { Index }\end{array}$ & $\begin{array}{c}\text { Expert's } \\
\text { Judgment }\end{array}$ \\
\hline $\begin{array}{c}\text { Sub-activity 1: } \\
\text { Seller-customer } \\
\text { selection }\end{array}$ & 88 & 0.88 & Accepted \\
\hline $\begin{array}{c}\text { Sub-activity 2: } \\
\text { Marketing planning }\end{array}$ & 86 & 0.86 & Accepted \\
\hline $\begin{array}{c}\text { Sub-activity 3: } \\
\text { Promotion time }\end{array}$ & 84 & 0.84 & Accepted \\
\hline $\begin{array}{c}\text { Sub-activity 4: } \\
\text { Bestseller award }\end{array}$ & 89 & 0.89 & Accepted \\
\hline Overall activities & $\mathbf{8 6 . 7 5}$ & $\mathbf{0 . 8 7}$ & Accepted \\
\hline
\end{tabular}

Refer to Table 3, the validity obtained for the entire activity was $0.87(86.75 \%)$ which was of high validity. Values for each activity in the module range from 0.84 to 0.89 , indicating that experts agree that module activity can influence metacognitive regulation and affect students' mastery in mathematics.

\subsection{Reliability of Module}

Table 4. Data Analysis of Reliability Testing

\begin{tabular}{cc}
\hline Activities of the M-ST Module & Cronbach Alpha \\
\hline Sub-activity 1:Seller-customer selection & 0.781 \\
\hline Sub-activity 2:Marketing planning & 0.859 \\
\hline Sub-activity 3:Promotion time & 0.843 \\
\hline Sub-activity 4:Best seller award & 0.625 \\
\hline Meta-Seller Tutoring Activity & 0.847 \\
\hline Reliability Coefficient of the Module & 0.953 \\
\hline
\end{tabular}

Table 4 shows the reliability values for the overall module activity as well as its subactivities. The obtained alpha value is 0.953 which indicates that this module has high reliability. According to Russell (1974), as mentioned in Madihie \& Noah (2013), participants can follow the module operation steps and procedures well, perform completely and then achieve the module's specific goals to gain module trust. Consequently, the findings of these alpha values show that each subactivity and overall M-ST activity is highly reliable and recognized around 0.625 and 0.859 . A minimum reliability index of 0.5 is reasonable for a module, as said by Valette (1977) as reported in Madihie $\&$ Noah (2013), but a better value than a module is being used in a real study should be at least 0.6 (Darussalam \& Hussin, 2018; Mohd Majid Konting, 2004). According to Nawi et al (2015), most researchers aim for reliability values to exceed 0.8 to demonstrate the quality of the developed module. Nevertheless, Othman Mohamed (2000) in Jalil \& Mahfar (2016) found the acceptable reliability index ranged from 0.65 to 0.85 for the development of new modules. The M-ST module has a reliability rating of 0.953 in this analysis, which is significant and accepted for the module to be used in the actual study of effectiveness.

\section{Implication and Suggestions}

The construction of this module is guided by the ADDIE Model, which is the teaching design model. This model is proven to be useful in designing a more systematic and practical learning activity. The steps suggested in this model are focused and specific process steps to ensure that the objectives of the development of the instructional product are met. The design and development of the M-ST module have followed the clear and systematic working steps as detailed in the ADDIE Model, therefore, the validity and reliability values obtained are high and the modules are acceptable and are ideal for experimental studies to see the effects on students in the actual study. Similar results have been obtained by most researchers who produce modules based on the ADDIE Model, including Nawi et al (2015), Nasohah, Abd Gani \& Mat Shaid (2015), Patel et al (2018), Bacotang \& Isa (2016) and Muslimin et al. (2017). This indicates that in producing a teaching module or an academic module, the design and development model must be accurate, appropriate and in line with the development objectives to be achieved.

Besides, the development of this module aims to produce interventions in mathematics learning. Applications of peer tutoring model and metacognitive learning strategies have been widely reported in previous studies. It has been proven that peer tutoring activities and metacognitive strategies are very important in affecting students' understanding of mathematics concepts as reported in the studies of $\mathrm{Al}$ Kharusi (2016), Hussein, Anwar \& Majoka (2011), Acar \& Ader (2017), Arrand (2017), Hott \& Walker (2012), Panaoura, Gagatsis \& Demetriou (2009), Hasbullah (2015), Su, Ricci \& Mnatsakanian (2017), Suriyon, Inprasitha \& Sangaroon (2017) and Menz \& Cindy Xin (2016). Mathematics achievement can also be improved based on these models. Therefore, through this study, based on the implications of previous studies on peer tutoring activities and metacognitive learning strategies, it is hoped that this module will have an impact on student mathematics learning and mastery. Accordingly, researchers made several suggestions, including:

1. Given that this module has high content validity and reliability, it is recommended that the use of this module be extended to various levels of students, both primary and secondary, for testing effectiveness

2. The development of this module is based on the ADDIE Model, so, it is recommended that future researchers also implement the same model to ensure that the new module has high validity and reliability and is very practical for use.

3. It is also suggested to future researchers, to obtain the validity and reliability of the module, model or instrument of study in future use and the use of the survey method can be practiced. 


\section{Conclusions}

The present study has successfully obtained the validity and reliability of the M-ST Module. The validity of the content indicates that this module intends to contribute to an alternative approach in mathematics learning activities. The value of reliability also reflects the use of modules in producing a meaningful mathematics learning environment by developing students' metacognitive skills through interactive and motivated activities. It is hoped that this module will contribute to educational institutions in the formulation of the mathematics curriculum as well as the contribution to the training of mathematics thinkers.

\section{REFERENCES}

[1] Acar, F. \& Ader, E. (2017). Metacognition Used By Tutors during Peer Tutoring Sessions in Mathematics. Elementary Education Online, 16(3), pp 1185-1200.

[2] Al Kharusi, D. (2016). What Positive Impacts Does Peer Tutoring Have Upon The Peer Tutors at SQU? Journal of Education and Practice, Vol.7, No.27.

[3] Arrand, K. (2014). Peer Tutoring. Journal Pedagogic Development, Volume 4 Issue 1.

[4] Anderson, N.J. (2002). The Role of Metacognition in Second Language Teaching and Learning. ERIC Digest, ERIC Clearinghouse on Languages and Linguistics. Washington DC.

[5] Bacotang, J. \& Isa, Z.M. (2016).Aplikasi Model ADDIE Dalam Pembangunan Modul Awal Literasi (Modul A-Lit) Untuk Kanak-Kanak TASKA. 1st International Teacher Education Conference on Teaching Practice (ITECTP) 2016, 8-10/10/16, Bangunan E-Learning, UPSI. Tanjung Malim, Malaysia.

[6] Benders, D.S.(2016).The Effect of Flexible Small Groups on Math Achievement in First Grade. An Online Journal for Teacher Research, Vol. 18, Issue 1.Issn 2470-6353.Spring.

[7] Celik, H.C.(2018).The Effects of Activity Based Learning on Sixth Grade Students' Achievement and Attitudes towards Mathematics Activities. EURASIA Journal of Mathematics, Science and Technology Education, 2018, 14(5), pp 19631977.

[8] Chris, O.(2015).Teaching Maths In The 21st Century. Changing The Focus From Calculations To Critical Thinking. Online: http://blog.learningbird.com.

[9] Darussalam, G \& Hussin, S. (2018). Research Methodology in Education. Practice and Research Analysis. 2nd Edition. Universiti Malaya Publisher. Kuala Lumpur, Malaysia.

[10] Du Toit, SD. \& Du Toit, GF. (2013).Learner metacognition and mathematics achievement during problem-solving in a mathematics classroom.TD The Journal for Transdisciplinary Research in Southern Africa, 9(3), Special edition, December 2013, pp. 505-518.

[11] Elliot, A. (1993). Metacognitive Teaching Strategies And
Young Children's Mathematical Learning. Proceeding Of Australian Association for Research in Education Conference, AARE. Fremantle.

[12] Fitch, M.A. \& Semb, G.B. (1993). The ASK Model of Peer Tutoring: Theory and Research. Navy Personnel Research and Development Center, San Diego, California.

[13] Festus, A.B. (213). Activity-Based Learning Strategies in Mathematics Classrooms. Journal of Education and Practice, Vol.4, No.13.

[14] Go Silk, C.J., Go Silk, B.B. \& Somblingo, R.A. (2017). Modular Approach in Teaching Problem Solving: A Metacognitive Process. International Journal of Science and Research (IJSR), Volume 6 Issue 8, August 2017. Doi: 10.21275/ART20175782

[15] Hasbullah (2015). The Effect Of Ideal Metacognitif Strategy on Achievement In Mathematics. International Journal of Educational Research and Technology, 6[4] 2015, pp 42-45. Doi: 10.15515/ijert.0976-4089.6.4.4245

[16] Hott, B. \& Walker, J. (2012). Peer Tutoring. Council for Learning Disabilities". Retrieved from: https://council-forlearning-disabilities.org/peer-tutoring-flexible-peermediated-strategy-that-involves-students-serving-asacademic-tutors

[17] Hussain, S. Anwar, S. \& Majoka, M.I. (2011). Effect Of Peer Group Activity-Based Learning On Students' Academic Achievement In Physics At Secondary Level. International Journal of Academic Research, Vol. 3. No.1. January 2011, Part iii,

[18] Jalil, N.I.A. \& Mahfar, M. (2016). The Validity and Reliability of Rational Emotive Behavioural Therapy Module Development for University Support Staff. Asian Social Science, Vol. 12, No. 2, pp 129-137.

[19] Lim, E.J.A. (2016). Effectiveness of Modular Instruction in Word Problem Solving of BEED Students. IOSR Journal of Mathematics (IOSR-JM), Volume 12, Issue 5 Ver. VII (Sep. - Oct.2016), pp 59-65. Doi: 10.9790/5728-1205075965

[20] Madihie, A. \& Noah, S.M. (2013). An Application of the Sidek Module Development in Rebt Counselling Intervention Module Design for Orphans. Procedia - Social and Behavioral Sciences, 84 ( 2013 ), pp 1481 - 1491.

[21] Menz, P. \& Cindy Xin (2016).Making Students' Metacognitive Knowledge Visible through Reflective Writing in a Mathematics-for-Teachers Course. Collected Essays on Learning and Teaching, Vol. IX. Simon Fraser University.

[22] Mohamed Arip, M.A.S., Bakar, R.A. Ahmad, A. \& Md. Jais, S. (2013). The Development of a Group Guidance Module for Student Self-development Based on Gestalt Theory. Procedia - Social and Behavioral Sciences, 84 ( 2013 ), pp $1310-1316$.

[23] Mohd Majid Konting (2004). Kaedah Penyelidikan Pendidikan. Kuala Lumpur: Dewan Bahasa dan Pustaka.

[24] Muslimin, M.S., Nordin, N.M., Mansor, A.Z. \& Yunus, M.M. (2017). The Design and Development of Mobieko: A Mobile Educational App for Microeconomics Module. Malaysian Journal of Learning and Instruction, Special Issues 2017, pp 221-255. 
[25] Nasohah,U.N., Abd Gani,M.I. \& Mat Shaid, N.(2015). Model Addie Dalam Proses Reka Bentuk Modul Pengajaran: Bahasa Arab Tujuan Khas Di Universiti Sains Islam Malaysia Sebagai Contoh. Proceedings of the International Seminar on Language Teaching ISeLT 2015, 4-5 February 2015, Bangi, Malaysia.

[26] Nawi, A., Zakaria, G.A.N., Hashim, N. \& Chua, C.R. (2015). Assessing the Quality of iPBL Module: Validity and Reliability Aspects. Journal of Quality Measurement and Analysis, JQMA, 11(2) 2015, pp 1-10.

[27] Nelson,T.O. \& Narens,L.(1990).Metamemory: A Theoretical Framework And New Findings. Psychology Of Learning And Motivation, Volume 26, 1990, pp 125-173.

[28] Noah, S.M. \& Ahmad, J. (2005). Module building: How to Build Exercise Module and Academic Module. Serdang, Malaysia, University Putra Malaysia Publisher.

[29] Panaoura, A., Gagatsis, A. \& Demetriou, A.(2009). An Intervention To The Metacognitive Performance: SelfRegulation In Mathematics And Mathematical Modeling. Acta Didactica Universitatis Comenianae Mathematics, Issue 9, 2009, pp. 63-79.

[30] Papaleontiou-Louca, E.(2008). Metacognition and Theory of Mind. Cambridge Scholars Publishing. 15 Angerton Gardens, Newcastle, NE5 2JA, UK.

[31] Paspasan, R.M. (2015). Structured Approach vs. Self-Paced Modular Approach in Teaching Trigonometry. Asia Pacific Journal of Multidisciplinary Research, Vol. 3 No.5, pp 5158.

[32] Patel, S.R., Margolies, P.J., Covell, N.H., Lipscomb, C. \& Dixon, L.B. (2018). Using Instructional Design, Analyze, Design, Develop, Implement, and Evaluate, to Develop eLearning Modules to Disseminate Supported Employment for Community Behavioral Health Treatment Programs in New York State. Curriculum, Instruction, and Pedagogy, Vol. 6. Doi: 10.8839/fpubh.2018.00113

[33] Phi, V.T.(2017). Developing Students Metacognitive Skills In Mathematics Classroom. Annals. Computer Science Series. Vol. xv fasc. 1-2017.

[34] Pilten, G. (2016). The Evaluation of Effectiveness of Reciprocal Teaching Strategies on Comprehension of Expository Texts. Journal of Education and Training Studies.Vol. 4, No. 10; October 2016. Doi:10.11114/jets.v4i10.1791

[35] Rillero, P.(2016).Deep Conceptual Learning in Science and Mathematics: Perspectives of Teachers and Administrators.Electronic Journal of Science Education, Vol. 20, No. 2.

[36] Schraw, G. \& Moshman, D. (1995). Metacognitive Theories. Educational Psychology Papers and Publications. 40 Online: http://digitalcommons.unl.edu/edpsychpapers/40

[37] Smith, J.M \& Mancy, R. (2018) Exploring The Relationship Between Metacognitive And Collaborative Talk During Group Mathematical Problem-Solving - What Do We Mean By Collaborative Metacognition? Research in Mathematics Education, 20:1 $14-36$ Doi:10.1080/14794802.2017.1410215.

[38] Su, H.F., Ricci, F.A., \& Mnatsakanian, M. (2016).
Mathematical Teaching Strategies: Pathways to Critical Thinking and Metacognition. Journal of Research in Education and Science (IJRES), 2 (1), pp 190-200.

[39] Suriyon, A., Inprasitha, M. \& Sangaroon, K.(2013). Students' Metacognitive Strategies in the Mathematics Classroom Using Open Approach. Psychology.2013. Vol.4, No.7, 585-591. Published Online July 2013 in SciRes (http://www.scirp.org/journal/psych)

[40] Zumbrunn, S., Tadlock, J. \& Roberts, E.D.(2011) Encouraging Self-Regulated Learning in the Classroom: A Review of the Literature. Metropolitan Educational Research Consortium (MERC), Virginia Commonwealth University. 